\title{
Sulodexide and Alzheimer's Disease: A Preliminary Prospective Study
}

\author{
Joaquín Lasierra-Cirujeda1*, María José Aza Pascual-Salcedo², \\ María Mercedes Aza Pascual-Salcedo ${ }^{3}$ \\ ${ }^{1}$ C. Medicine Hematology, Logroño, Spain \\ ${ }^{2}$ The Rioja and Pharmaceutical Act, Ministry of Health, The Rioja Regional Government, Logroño, Spain \\ ${ }^{3}$ Aragon Health Service, Zaragoza, Spain \\ Email: "hematol@telefonica.net
}

Received 13 January 2016; accepted 21 February 2016; published 24 February 2016

Copyright (C) 2016 by authors and Scientific Research Publishing Inc.

This work is licensed under the Creative Commons Attribution International License (CC BY).

http://creativecommons.org/licenses/by/4.0/

(c) (i) Open Access

\section{Abstract}

The purpose of this prospective study is to determine the relative incidence of Alzheimer's disease in patients treated for at least three years, with sulodexide $(n=46,76.48 \pm 7.02$ years old $)$ or acenocoumarol $(n=47,78.21 \pm 6.66$ years old) in order to prevent primary and secondary venous thromboembolism and atherothrombotic disease. In the sulodexide group, there was an apparent prevention of cognitive and behavioural impairment (relative incidence: 2.02) compared with acenocoumarol group (relative incidence: 4.86 ). The favourable results in sulodexide group may be related to their pharmacodynamic actions of inhibition of PAI-1, which may interfere with the pathogenesis of Alzheimer's disease, and to the role of glutathione and PAI-1 in the $\beta$-amyloid system in the brain.

\section{Keywords}

\section{Sulodexide, Alzheimer's Disease, Glutathione, t-PA, PAI-1, Plasminogen, Plasmin}

\section{Introduction}

Advanced age is the single most important risk factor known to be associated with cognitive alterations and neurodegenerative diseases. Among these conditions, the irreversible and incurable senile dementia known as Alzheimer's disease (AD) is included [1] [2].

From the anatomopathological point of view, the typical cerebral lesions of $\mathrm{AD}$ are characterized by the presence of $\beta$-amyloid (A $\beta$ ) peptides formed from the endoproteolysis of the amyloid precursor protein (APP) through the activity of the $\beta$-secretase enzyme (BACE 1) [3]-[9]. The A $\beta$ peptide is mostly deposited in the cor-

\footnotetext{
"Corresponding author.
}

How to cite this paper: Lasierra-Cirujeda, J., Aza Pascual-Salcedo, M.J. and Aza Pascual-Salcedo, M.M. (2016) Sulodexide and Alzheimer's Disease: A Preliminary Prospective Study. World Journal of Cardiovascular Diseases, 6, 54-71. 
tex, hippocampus, and other regions of the brain in the form of amyloidal plaques or neurovascular infiltration [10]. The accumulated deposits of $\mathrm{A} \beta$ in the cerebral parenchyma have a neurotoxic effect and play a central role in the etiology of $\mathrm{AD}[11]$ [12].

The $\mathrm{A} \beta$ peptide is a substratum capable of being degraded, via beta-amyloidolysis [13], by various proteases known as $\mathrm{A} \beta \mathrm{DPs}$ (A $\beta$-degrading proteases) [14]. Among all $\mathrm{A} \beta \mathrm{DPs}$ that can degrade the $\mathrm{A} \beta$ peptides, for their clearing and cerebral elimination, such as neprilysin (NEP) [15]-[24], insulin-degrading enzyme (IDE) [16] [25]-[27], and plasmin [28]-[33].

The extent of accumulation of the $\mathrm{A} \beta$ peptides depends on an imbalance between their production, proteolytic degradation and cerebral elimination [34], being the relationship between glutathione (GSH or L-gamma-glutamyl-L-cysteinyl-glycine) and plasminogen/plasmin system of great importance for normal cerebral function, since the deficit of $\mathrm{A} \beta$-degrading enzymes and the decrease of GSH affect the $\mathrm{A} \beta$ balance in aging, and are very important mechanisms in the brain accumulation of $\mathrm{A} \beta$ [13] [35]. Several groups of investigators have suggested the possibility that the amyloidal deposits may be amenable by these proteases. In fact, they play an important role in the regulation of $\mathrm{A} \beta$ brain accumulation, they may also represent a target of therapy with possibility of exercising pharmacological action to be able to prevent and to treat AD [16] [24] [36]-[40].

In the study a population of patients older than 65 years distributed in two groups receiving long-term treatment with the glycosaminoglycan sulodexide (SLX) y acenocoumarol (0A), a beneficial effect of prevention of decay of both cognitive state and behavior in SLX. This effect leads us to assume that it is achieved through those pharmacodynamic properties of sulodexide, consisting in the reduction of plasminogen activator inhibitor (PAI-1) activity and in the increase of tissue plasminogen activator (t-PA), as well as in its pro-fibrinolytic activities [41].

\section{Material and Methods}

In this prospective not randomized study, we included 93 patients all aged over 65 years who, from 2000 to 2010 , had been treated for three or more years with sulodexide $(n=46)$ or acenocoumarol $(n=47)$ for prevention primary and secondary venous thromboembolic and atherothrombotic diseases.

Selection of the patients. The patients come from external consultations directed by family doctors of the Social Security of the Community (Logroño, La Rioja) and of our consultation of the CMH (C. Medicine Hematology, Logroño, La Rioja). All patients were recruited under the following conditions: 1) Patient of both sexes $\geq$ of 65 years old. 2) At the beginning of treatment, none of the patients in both groups presented signs of cognitive disorders or abnormalities that would have excluded them from the recruitment. 3) Treatment pharmacological with Sulodexide/Acenocoumarol for at least three years without interruption until the recruitment. 4) During the preventive treatment in both groups none of the patients had suffered hemorrhagic processes or thromboembolic systemic or cerebral processes. 5) The clinical follow-up of the patients was carried out by their own family doctors. 6) The final evaluation of cognitive evolution of the patients was performed by neurologists.

SULODEXIDE (SLX) group: was formed by 46 patients with an average age of $76.48 \pm 7.02$ years. In this group, 21 patients were women and 25 men. The average age of the women was $77.0 \pm 7.89$ years and that of men was $76.04 \pm 6.33$ years. Sulodexide was administered at a dosage of 300 LSU [lipasemic units (approximately corresponding to $30 \mathrm{mg})]$ every 12 hours.

ACENOCOUMAROL (OA) group: was formed by 47 patients with an average age of $78.21 \pm 6.66$ years. In this group, 24 patients were women and 23 men. The average age of the women was $79.00 \pm 7.42$ years and that of men was $77.32 \pm 5.71$ years. The patients were controlled in our unit (CMH) for the adjustment of the anticoagulant medication in a periodic way ( $\approx$ every 21 - 25 days) maintaining an International Normalized Ratio (INR) (Protime 3) among 2.0 - 3.0. Age groups of the patients and age averages of patients are showed in Figure 1 and Figure 2 respectively.

Patients in both groups were suffering from various diseases common to their advanced age. These diseases are specified here below:

SLX group: cardiac pathology in 16 patients (34.7\%), arteriovascular or venous diseases in 27 (58.7\%), type 2 diabetes mellitus (T2DM in 8 (17.4\%), dyslipidemia in 17 (36.9\%), arterial hypertension (AH) in 21 (45.6\%), hyperuricaemia in 3 (6.4\%), and miscellaneous diseases in 8 patients (17.35\%).

OA group: cardiac pathology in 31 patients (65.9\%), arteriovascular or deep venous thrombosis (DVT) in 18 


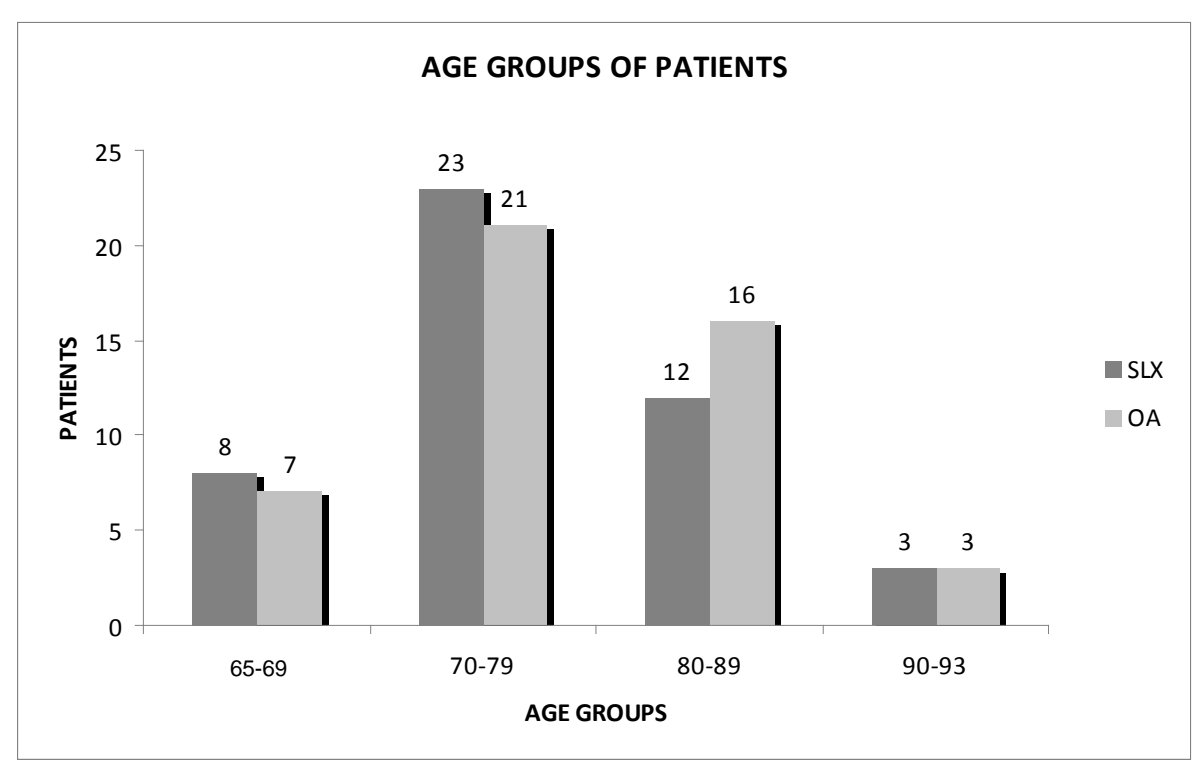

Figure 1. Age groups of the patients.

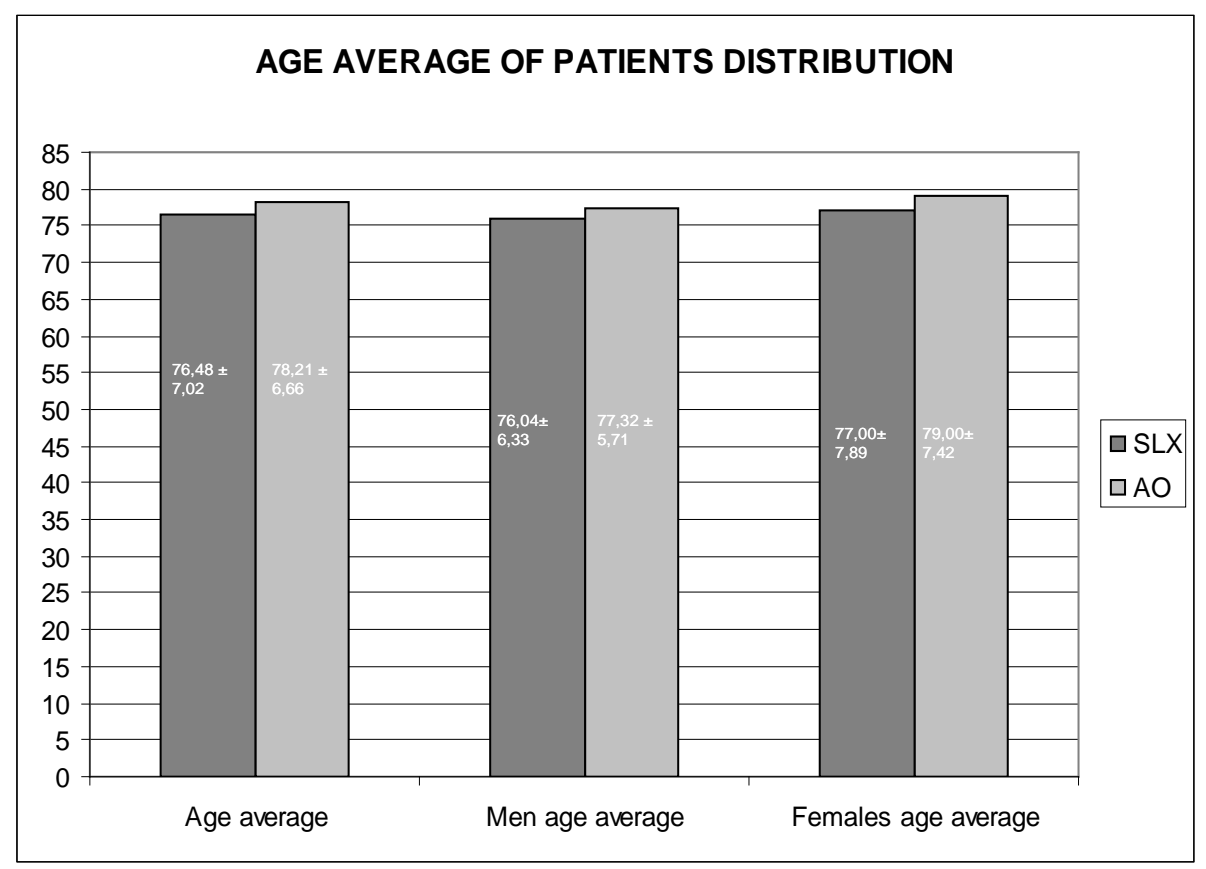

Figure 2. Age average of patients distribution.

(38.3\%), type 2 diabetes mellitus (T2DM) in 10 (21.2\%), dyslipidemia in 13 (27.7\%), arterial hypertension (AHT) in 17 (36.2\%), hyperuricaemia in 3 patients (6.4\%), and miscellaneous diseases in 6 patients (12.8\%) (Figure 3). The load of chronic illnesses for the patients in the group SLX was of $2.690 \pm 0.9859$ and for the group OA was $2.7021 \pm 0.9536$.

Associated medications: numerous medications were used based on the complex diseases of the patients in the study, according to their advanced age. The associated medications were the following: antihypertensives, diuretics, oral antidiabetics, dislypemics, cardiac tonics, ASA, allopurinol, NSAIDs, betablockers, sleeping pills and omeprazol. The load of medications for the group SLX was $3.80 \pm 0.89 /$ patient and for the group OA was $4.91 \pm 1.60$ /patient.

Clinical evaluation of cognitive/intellectual state: it was carried out according to the criteria of the Mini Mental 


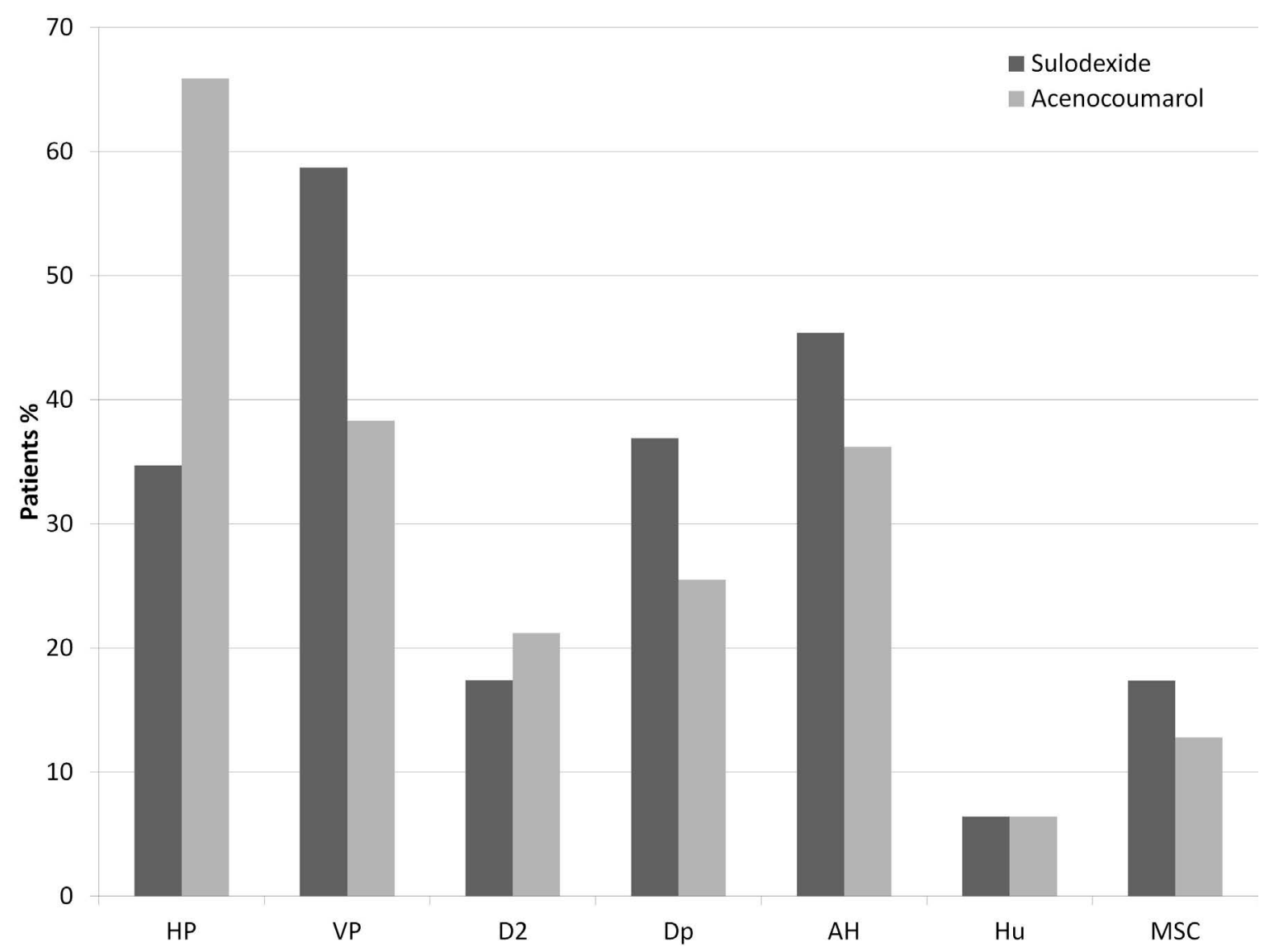

Figure 3. Associated pathology in groups of patients. HP: Cardiac pathology. VP: Vascular pathoology. D2: T2DM. Dp: Dyslipidemia. AH: Arterial hypertension. Hu: Hyperuricemia. MSC: Miscelanea.

State Examination (MMSE) and GENCD [42] [43]. The conclusion of the study was marked by a final evaluation of the patients' clinical symptomatology in areas related to cognitive state, such as actual memory loss, difficulties in orientation, and deterioration of self-sufficiency as well as deterioration of recognition of objects and people, irritability/aggression and disorganized language.

Nuclear Magnetic Resonance (NMR): not all the patients that showed signs of altered cognitive state were tested with NMR.

Statistical analysis: the data were examined in both groups for the estimate of their incidence rate [44].

\section{Results}

The study was carried out with the purpose of determining the relative incidence of Alzheimer's disease in two groups of patients under treatment for the primary or secondary prevention thromboembolic venous and atherothrombotic diseases.

The clinical valuation in both groups were determined by significant as initial symptom the loss current or short term as cognitive deterioration accompanied by the difficulty of new learning, as well as, the problem of the family coexistence. The patients' affections of the short term loss of the memory with bigger or smaller loss of the historical memory have been considered as Incipient Alzheimer disease (IAD). The pathological evolution of the clinic with new parameters such as recognition of objects and people, irritability or aggressiveness the patients are classified as Middle Alzheimer's Disease (MAD), and their hospital entrance with loss of the selfsufficiency and the necessity of a constant supervision the patients are considered as Serious Alzheimer disease (SAD).

SLX group. Patients in the sulodexide group were continuously treated with sulodexide for an average time of $6.37 \pm 2.75$ years. Among the 46 patients recruited, five patients are diagnosed of AD that they are exposed 
next to the comorbility, that is to say, the diagnoses that exist simultaneously independent of the AD. Two females, one of 80 years old with AH and DVT who had an evident loss of memory and orientation difficulties which required assistance and whose NMR study showed areas of cerebral infarctions, and a woman aged 77 years with a history of an old cerebrovascular accident (CVA), AH and DVT are diagnosed as MAD. A 73 year-old man with $\mathrm{AH}$, dyslipidemia and atherosclerosis and two women, both of 72 years, one with $\mathrm{AH}$, dyslipidemia and DVT and the other one with T2DM and atherosclerosis.

Two woman died one of them at age 68 from colon carcinoma and circulatory inadequacy, and the other one $t$ died at age 93 year old from diabetic coma after a complicated medical history of A MI, T2DM, hypercholesterolemia and DVT. Two patients were diagnosed of irritability without aggressiveness, one woman 73 years old with circulatory Inadequacy, AMI and hypercholesterolemia, and a man 85 years old with DVT and AH, both with the other parameters remained normal. The remaining patients showed no significant changes in the parameters tested.

OA group. In the group OA were continuously treated with acenocoumarol for an average time of $6.84 \pm 3.1$ years. The periodic controls of the anticoagulant treatment for their drug adjustment, showing $91.58 \%$ inside the range INR among 2.0 - 3.0, 7.22\% > 3.0 (INR among $3.1-5.0$ ) and $1.20 \%<2.0$ (INR among 1.9 - 1.6) The mean of the INR of the patients with diagnose of AD it is of $2.5135 \pm 0.7804$.

In this group 14 patients are diagnosed of $\mathrm{AD}$ : Six patients of $\mathrm{SAD}$, two patients of MAD and six patients of IAD. The comorbility has been: Cardiac pathology, Atrial fibrillation (AF) 85.7\%, others heart pathology, 10.1\%, AH, 50\%, DVT 42.8\%, dyslipidemia, 35.7\%, atherosclerosis 35.7, T2DM, 21.4\%.

Of the 6 patients with diagnose of SAD, three died, two men 86 and 91 year-old and a woman of 90 years old respectively. Of the three remaining patients we found two women one of 80 years with AHT, hypercholesterolemia, DVT, and atherosclerosis, and another woman of 92 years old with AF, AH, and DVT, and a man of 69 years old with AF, AH and DVT. In two patients find lesion consistent with cerebral infarctions on NMR testing. Two patients of MAD are women of 87 years old with AF and DVT, and the other one 79 years old with AF, DM and venous disease. Six patients are of IAD, 4 women and 2 men. One woman of 83 years old with FA, AH, DVT and, T2DM, two men, one of them of 80 years old with DM and DVT, an another of $80 \mathrm{~m}$ years old with $\mathrm{AF}, \mathrm{AH}$, and IC. Tree women, one of them of 80 years old with AF,IC, another of 80 years ol with AF and the last one of 76 years old with AF, hypercholesterolemia, AH and IC.

Three patients, one woman of 84 years old with AF AH and T2DM died of AMI and two men, one of 62 years old with dyslipidemia and the other one 82 years old with AF and T2DM died of lung cancer and cardiac disease respectively.

The relative incidence AD for groups of ages, gender and cases/year/100 patients they are exposed in the Table 1.

Adverse effects caused by sulodexide or acenocoumarol during the course of the study don't required to stop the treatment.

\section{Discussion}

This preliminary study prospective seek to determine the relative incidence (RI) of Alzheimer's disease in two

Table 1. Relative incidence (RI) of AD in the group SLX and OA both sexes.

CASES/YEAR/100 PATIENTS

\begin{tabular}{ccccc}
\hline & \multicolumn{2}{c}{ SLX } & \multicolumn{2}{c}{ OA } \\
\hline Range years & RI & Cases M/FM & RI & Cases M/FM \\
\hline $65-69$ & 0 & - & 2.78 & $1 / 0$ \\
$70-79$ & 3.31 & $1 / 3$ & 1.45 & $0 / 2$ \\
$80-89$ & 1.58 & $0 / 1$ & 7.07 & $3 / 5$ \\
$90-93$ & 0 & - & 18.75 & 4.86 \\
All ages & 2.02 & $1 / 4$ & $4 / 9$ \\
\hline
\end{tabular}

AD: Alzheimer diseases; SLX: Sulodexide; OA: Oral anticoagulation; M: males; FM: females. 
groups of patients $\geq 65$ years receiving treatment for prevention of venous thromboembolic and atherothrombotic diseases.

An increment of the venous and arterial thromboembolic diseases has been observed in the development of the aging [45], being attributed at a state prethrombotic like shows for the hypercoagulability activity found in blood [46] [47]. Sulodexide (SLX) or vitamin K antagonist (AVK) (Warfarina, Acenocoumarol) in the old patients is a medication prescribed in first line, being indicated in the illnesses of thromboembolic risk and stroke [48]-[51]. Although thromboembolic disease is related to the great activity or concentration of some factors of the blood coagulation in the aging, there is some scientific evidence of a decrease of the systemic fibrinolytic activity [47] [52] due to an increase in the expression of PAI-1 main inhibitor of the plasminogen activator tissue [3] [46] [53] that play a very important role in the thromboembolic disease, metabolic disease, T2DM and AD associated clinical processes with GSH depletion [54]-[57].

The patients recruited for this preliminary prospective study with the mentioned characteristics previously, suppose two different methodologies of prevention of the thromboembolic diseases in a population of patient with a high risk and incidence of thromboembolic complications. The group SLX is subjected to treatment with Sulodexide oral with fixed dose that doesn't need to be monitored and whose main pharmacological effect is referred as an inhibitor PAI with an increase of the fibrinolytic activity, and the group OA in treatment with vitamin $\mathrm{K}$ antagonist (VKA) that requires periodic monitoring for the adjustment of the INR, being both effective drugs in the prevention of the thromboembolic disease [58].

In connection with the group OA made up with patient affections of AF in their biggest part, clinical impression exists among the specialists that it can have certain relationship among the INR of the patients with AF and the cognitive state, referred mainly to that the alteration of the cognitive function could be related with a smaller effectiveness of the anticoagulation. However, this clinical appreciation has not been enough documented [49] [59]-[62]. Our results show as $91.58 \%$ recruited patients have been inside an INR among 2.0 - 3.0 appropriate range for the anticoagulation to patient with AF [63] [64], and only a $1.2 \%$ of them have been below the range and $7.2 \%$ for above of recommended range. In the same line, the results of the INR of the patients with AO and diagnose of AD they have been inside the range $2.5135 \pm 0.7804$.

The patients in this study are representative of a population older than 65 years, and it is important to point out that the patients in both groups, due to their advanced age, had a great load of chronic diseases such as cardiac diseases, dyslipidemia, arterial hypertension, type 2 diabetes mellitus, etc. They were under continuous follow-up and treatment by their family doctors. These chronic diseases in these patient groups require some comments because many of diseases and conditions inherent to them have been considered as AD risk factors by some researchers. Cardiovascular disorders (AF, IMA), AH, dyslipidemia and T2DM of mild cognitive impairment syndrome with high risk of progression to AD [64]-[67]. Numerous studies show that AH is associated with an increment of AD incidence and that early treatment of AH could be very important for the AD prevention [68]-[77]. Dyslipidemia and more specifically hypercholesterolemia has also been considered as possible risk factor in the development of $\mathrm{AD}$ [78]-[82]. This suggests that the treatment of these conditions may also be important for the prevention and treatment of AD [68] [83]-[86]. Nevertheless, in some studies in dyslipidemia, hypercholesterolemia could not be closely associated with the risk of development of AD [86]-[90]. T2DM is associated with an increment of risk of AD [91]-[99]. A close relationship is even suggested between both diseases [100] [101]. The patients of both groups had been followed and treated by their family doctors and the treatment for these diseases may have had some beneficial effects on maintaining the cognitive and mental health, although the exact mechanism of these diseases as risk factors in AD has not yet been clarified [78] [82]-[84] [89].

Common $\mathrm{AD}$ is a chronic process of complex etiology, without any effective prevention and treatment just until now. The results found in our study show the difference in cognitive and behavior evolution between sulodexide and acenocoumarol groups (Table 1).

In our opinion, the clinical benefit that we have found in the sulodexide group of patients, might be attributable to the properties of this drug on the fibrinolytic system t-PA/plasminogen/plasmin at systemic level and, in hypothesis, on the corresponding cerebral $\beta$-amiloidolytic mechanism [13] that will be discussed below.

The pharmacodynamic activity of sulodexide in the fibrinolytic system [41] is due to the increase of t-PA activity and the inhibition of PAI-1 activity [102]-[110]. After a quick and progressive intestinal absorption following oral administration of sulodexide [111], a remarkable plasmatic concentration and a generalized distribution occurs mainly in the endothelial cells due to its affinity to this cellular layer [39] [112]-[115]. The sulodex- 
ide property of increasing fibrinolytic/proteolytic capacity would suggest that its long-term administration would bring, after passing the blood-brain barrier (BBB) of the proteoglycans [114] [115], an equilibrium between production and degradation of amyloid material with a greater clearing and a lesser accumulation of amyloid material (this last crucial to the progression of AD) in the cerebral regions [39].

The cerebral plasminogen/plasmin system does not differ from the systemic plasminogen/plasmin system, since all the constituents of the systemic mechanism are present in the brain [116]-[118]. Several studies have demonstrated the importance of the plasminogen/plasmin mechanism in the central nervous system [14] [119] and its implication in AD [31] [32] [120]-[122].

Along the aging there is a progressive descent of fibrinolytic activity due to a decrease of plasmin as it was observed in the serum of patients with Alzheimer type dementia [123] and in healthy subjects [124]. This decrease of plasmin with an increase in the levels of PAI- 1 entails a decrease of $\beta$-amiloidolytic activity in the brain, which leads to an increase in the accumulation and to a decrease in the clearing of $\mathrm{A} \beta$, and represents a very important mechanism in the pathogenesis of AD [34] [35] [119] [125] [126] in close correlation with the GSH mechanism.

We reported, in fact, that the pharmacological effect that is obtained after the administration of buthionine sulfoximine (BSO) or dietil maleate in rabbits, is a significant decrease in the levels of GSH with the inhibition of fibrinolytic activity measured in the fibrin plates, due to a decrease of cellular t-PA release with a significant increase of its inhibitor PAI-1 [13] [127].

Therefore, this systemic decrease of GSH by BSO suggests the following hypothesis: if cerebral plasminogen/plasmin system does not differ from the systemic plasminogen/plasmin system, it will be possible that the decrease of cerebral GSH levels, that is a fact in the physiologic aging as well as in AD, it may be the origin of the alteration of the cerebral protein homeostasis (proteostasis) characterized by deficit of the different cerebral proteolytic systems as neprilysin (NEP), insulin-degrading enzyme (IDE), endothelin-converting enzymes (ECE 1 and 2), and plasmin, with increments of the inhibitor PAI-1 [17] [21] [22] [25] [128]-[136]. In this line, it was reported that amyloid deposition in the brain was increased in PAI-1 transgenic mice, suggesting that increased PAI-1 expression contributes to the development of amyloidosis in AD [25] [137]-[139]. These scientific evidences lead us to think that GSH can play an essential role in the regulation of the different components of the brain proteolytic system.

GSH plays very important parts in many biological activities in the homeostasis of the organism, standing out for its capacity to neutralize the free radicals that origin reactive species of oxygen (ROS), due to its great antioxidant activity [140]-[144].

Many of the cerebral functions are altered as consequence of the decrease of the intra- and extracellular levels of GSH [144]-[151] as a result of the inhibition of GSH synthesis, due to the reduction of the enzymatic capacity of glutamylcysteine synthetase (GCS) that catalyzes the synthesis of GSH, and to the increased consumption of brain GSH due to age [152]-[156].

Deficiency of GSH is found in neurodegenerative diseases, mainly Alzheimer's and Parkinson's diseases, [146] [153]-[159] in patients with obesity, metabolic syndrome, resistance to insulin, hyperglycemia and diabetes, clinical conditions very related with AD [160]-[165]. In fact, an important decrease of fibrinolytic activity, with a depletion of t-PA activity, an increase of PAI-1 and an enhanced production of ROS has been found in these metabolic diseases [166]-[177].

Transforming grow factor-beta 1 (TGF- $\beta 1$ ) is a factor that plays an important role in the proteolytic mechanism plasminogen/plasmin through GSH. TGF- $\beta 1$ induces PAI-1 expression and activity with inhibition of t-PA and plasmin activities, whereas supplementation with GSH restores t-PA and plasmin activities by inhibition of TGF- $\beta 1$-induced PAI expression and activity [178]-[180]. In vitro, TGF- $\beta 1$ reduces the intracellular concentration of GSH [178] in a similar way to BSO [127]. This effect leads to a decrease of the t-PA and plasmin activities and an increase of PAI-1. The normalization of the concentration of GSH after the suspension of the effect of BSO is accompanied by normal t-PA and plasmin activities [127]. There are elevated serum concentrations of TGF- $\beta 1$ in obesity, metabolic syndrome, type 2 Diabetes mellitus and AD [180]-[183] which are pathogenic processes entailing increase of PAI-1 and decrease of the level of GSH [166]-[168]. In addition to this, an improvement of the fibrinolytic activity and a decrease of PAI-1 have been observed with the administration of GSH to patients with non-insulin-dependent diabetes mellitus (NIDDM) [184] [185]. Experimental data show that a small molecule, PAZ-417, which is an inhibitor of PAI-1, increases t-PA activity, generates plasmin and enhances the degradation of $\mathrm{A} \beta$ in vitro and in vivo [33]. In the same line, in an experimental study in $\mathrm{A} \beta \mathrm{PP} / \mathrm{PS} 1$ 
double transgenic mice, a model of familial $\mathrm{AD}$, a diet containing the phenolic compound tert-butyl hydroquinone (TBHQ) reduced the brain A $\beta$ load, which was associated with an inhibition of PAI- 1 and TGF- $\alpha$-induced PAI-1 expressions and an increase in the activity of t-PA, plasmin, and the concentration of GSH [139]. These scientific evidences support the central role that PAI-1 plays in metabolic and neurodegenerative processes, especially in the $\mathrm{AD}$, and suggest that agents inhibiting PAI-1 increase the plasminic activity.

The result in the SLX group of an apparent prevention of cognitive deterioration compared to the OA group leads us to highlight the benefits of the inhibition of the overexpression of PAI-1 and of the increase of the t-PA activity following the sulodexide administration [123]. There is some clinical evidence to suggest that cognitive status can be improved by decreasing the concentration of $\mathrm{A} \beta$ peptide in the cerebrospinal fluid, and that shortterm and long-term resistance to cognitive deterioration can be achieved by oral administration of sulodexide. In line with our study some researchers present some evidences of clinical improvement of the cognitive state after short-term and long-term oral administration of sulodexide. Clinical improvement of memory deficit is described [186] as well as improvement of dementia symptomatology [187] [188] and mental confusion, [189][191] and a remarkable improvement of psycho-sensorial disturbances, sleeping disorders [192] and beneficial effects in vascular dementia [193].

Finally, the clinical benefit found in the group of patients receiving long-term treatment with sulodexide suggests in hypothesis, that the pharmacodynamic activity of sulodexide inhibiting PAI-1 and activating t-PA which leads to a permanent increase of cerebral plasmin activity, favors the catabolism of the $\mathrm{A} \beta$ peptide and the inhibition of its excessive extracellular accumulation.

It is possible that the cerebral mechanisms of GSH and $\beta$-amyloidolysis, can be some fundamental pillars in the prevention of $\mathrm{AD}$, because their normal function during the aging brings the subjects to become centenarians. In fact, in centenarians glutathione reductase activity (leading to GSH synthesis) is normal or high [194] [195] and t-PA/plasminogen/plasmin and PAI-1 mechanisms are normal with a paradoxical increase of secondary fibrinolytic activity with high levels of D-dimer and plasmin-antiplasmin complex which are demonstrative parameters of a bigger fibrinolytic activity [196] [197].

\section{Conclusions}

Sulodexide prevents the depth and the relative incidence of the cognitive deterioration in patients older than 65, in treatment for more than 3 years apparently.

This favourable result may be related to its pharmacodynamic actions of inhibition of PAI-1. PAI-1 is the origin of the decrease of systemic fibrinolytic and cerebral proteolytic activities and it causes some thromboembolic complications so frequent in these patients. The clinical benefit found in the group of patients receiving long-term treatment with sulodexide suggests us in hypothesis, that the pharmacodynamic activity of sulodexide inhibiting PAI-1 and activating t-PA which leads to a permanent increase of cerebral plasmin activity, favours the catabolism of the $\mathrm{A} \beta$ peptide and the inhibition of its excessive extracellular accumulation. The possible causal agent may be the decrease of GSH synthesis which may interfere with the pathogenesis of Alzheimer's disease. It is possible that the cerebral mechanisms of GSH and fibrinolysis/ $\beta$-amyloidolysis, can be fundamental pillars in the prevention of Alzheimer disease.

Further prospective clinical trials are needed to evaluate the cognitive state of patients during long-term treatment with PAI-1 inhibitors, such as sulodexide, as well as to investigate more deeply the relationship of GSH with the different components of proteolytic cerebral system in common AD.

\section{Acknowledgements}

Our gratefulness to all those that have collaborated in this study: family doctors, chemists and especially to the patients and families.

\section{Disclosure}

The authors report no conflicts of interest in this work.

\section{References}

[1] Jorm, A.F., Korten, A.E. and Henderson, A.S. (1987) The Prevalence of Dementia: A Quantitative Integration of the 
Literature. Acta Psychiatrica Scandinavica, 76, 465-479. http://dx.doi.org/10.1111/j.1600-0447.1987.tb02906.x

[2] Brookmeyer, R., Gray, S. and Kawas, C. (1998) Projections of Alzheimer's Disease in the Unites States and the Public Health Impact of Delaying Disease Onset. American Journal of Public Health, 88, 1337-1342. http://dx.doi.org/10.2105/AJPH.88.9.1337

[3] Hussain, I., Powell, D.J., Howlett, D.R., Tew, D.G., Meek, T.D., Chapman, C., et al. (1999) Identification of a Novel Aspartic Protease (Asp 2) as $\beta$-Secretase. Molecular and Cellular Neuroscience, 14, 419-427. http://dx.doi.org/10.1006/mcne.1999.0811

[4] Sinha, S., Anderson, J.P., Barbour, R., Basi, G.S., Caccavello, R., Davis, D., et al. (1999) Purification and Cloning of Amyloid Precursor Protein Beta-Secretase from Human Brain. Nature, 402 , 537-540. http://dx.doi.org/10.1038/990114

[5] Vassar, R., Bennett, B.D., Babu-Khan, S., Khan, S., Mendiaz, E.A., Denis, P., et al. (1999) Beta-Secretase Cleavage of Alzheimer's Amyloid Precursor Protein by the Transmembrane Aspartic Protease BACE. Science, 286, 735-741. http://dx.doi.org/10.1126/science.286.5440.735

[6] Yan, R., Bienkowski, M.J., Shuck, M.E., Miao, H., Tory, M.C., et al. (1999) Membrane-Anchored Aspartyl Protease with Alzheimer's Disease Beta-Secretase Activity. Nature, 402, 533-537. http://dx.doi.org/10.1038/990107

[7] Lin, X., Koelsch, G., Wu, S., Downs, D., Dashti, A. and Tang, J. (2000) Human Aspartic Protease Memapsin 2 Cleaves the Beta-Secretase Site of Beta-Amyloid Precursor Protein. Proceedings of the National Academy of Sciences of the United States of America, 97, 1456-1460. http://dx.doi.org/10.1073/pnas.97.4.1456

[8] Vassar, R. (2002) Beta-Secretase (BACE) as a Drug Target for Alzheimer's Disease. Advanced Drug Delivery Reviews, 54, 1589-1602. http://dx.doi.org/10.1016/S0169-409X(02)00157-6

[9] Cole, S.L. and Vassar, R. (2007) The Alzheimer's Disease Beta-Secretase Enzyme, BACE1. Molecular Neurodegeneration, 2, 22. http://dx.doi.org/10.1186/1750-1326-2-22

[10] Selkoe, D.J. (1991) The Molecular Pathology of Alzheimer's Disease. Neuron, 6, 487-498. http://dx.doi.org/10.1016/0896-6273(91)90052-2

[11] Hardy, J. and Selkoe, D.J. (2002) The Amyloid Hypothesis of Alzheimer's Disease: Progress and Problems on the Road to Therapeutics. Science, 297, 353-356. http://dx.doi.org/10.1126/science.1072994

[12] Deane, R. and Zlokovic, B.V. (2007) Role of the Blood-Brain Barrier in the Pathogenesis of Alzheimer's Disease. Current Alzheimer Research, 4, 191-197. http://dx.doi.org/10.2174/156720507780362245

[13] Lasierra-Cirujeda, J., Coronel, P., Aza, M.J. and Gimeno, M. (2013) Beta-Amyloidolysis and Glutathione in Alzheimer's Disease. Journal of Blood Medicine, 4, 31-38. http://dx.doi.org/10.2147/JBM.S35496

[14] Saido, T. and Leissring, M.A. (2012) Proteolytic Degradation of Amyloid $\beta$-Protein. Cold Spring Harbor Perspectives in Medicine, 2, a006379. http://dx.doi.org/10.1101/cshperspect.a006379

[15] Howell, S., Nalbantoglu, J. and Crine, P. (1995) Neutral Endopeptidase Can Hydrolyze Beta-Amyloid(1-40) but Shows No Effect on Beta-Amyloid Precursor Protein Metabolism. Peptides, 16, 647-652. http://dx.doi.org/10.1016/0196-9781(95)00021-B

[16] Takaki, Y., Iwata, N., Tsubuki, S., Taniguchi, S., Toyoshima, S., Lu, B., et al. (2000) Biochemical Identification of the Neutral Endopeptidase Family Member Responsible for the Catabolism of Amyloid Beta-Peptide in the Brain. The Journal of Biochemistry, 128, 897-902. http://dx.doi.org/10.1093/oxfordjournals.jbchem.a022839

[17] Iwata, N., Tesubuki, S., Takaki, Y., Shirotani, K., Lu, B., Gerard, N.P., et al. (2001) Metabolic Regulation of Brain Abeta by Neprilysin. Science, 292, 1550-1552. http://dx.doi.org/10.1126/science.1059946

[18] Shirotani, K., Tsubuki, S, lwata, N., Takaki, Y., Harigaya, W., Matuyama, K., et al. (2001) Neprilysin Degrades both Amyloid Beta Peptides 1-40 and 1-42 Most Rapidly and Efficiently among Thiorphan- and Phosphoramidon-Sensitive Endopeptidases. The Journal of Biochemistry, 276, 21895-21901. http://dx.doi.org/10.1074/jbc.M008511200

[19] Leissring, M.A., Farris, W., Chang, A.Y., Walsh, D.M., Wu, X., Sun, X., et al. (2003) Enhanced Proteolysis of Beta-Amyloid in APP Transgenic Mice Prevents Plaque Formation, Secondary Pathology, and Premature Death. Neuron, 40, 1087-1093.

[20] Marr, R.A., Rockenstein, E., Mukherjee, A., Kindy, M.S., Hersh, L.B., Gage, F.H., et al. (2003) Neprilysin Gene Transfer Reduces Human Amyloid Pathology in Transgenic Mice. The Journal of Neuroscience, 23, 1992-1996.

[21] Caccamo, A., Oddo, S., Sugarman, M.C., Akbari, Y. and LaFerla, F.M. (2005) Age and Region-Dependent Alterations in Abeta-Degrading Enzymes: Implications for Abeta-Induced Disorders. Neurobiology of Aging, 26, 645-654. http://dx.doi.org/10.1016/j.neurobiolaging.2004.06.013

[22] Eckeman, E.A. and Eekeman, C.B. (2005) Abeta-Degrading Enzymes: Modulators of Alzheimer's Disease Pathogenesis and Targets for Therapeutic Intervention. Biochemical Society Transactions, 33, 1101-1105.

[23] Eckman, E.A., Adams, S.K., Troendle, F.J., Stodola, A., Kanh, M.A., Faugh, A.H., et al. (2006) Regulation of Steady- 
State Beta-Amyloid Levels in the Brain by Neprilysin and Endothelin-Convertig Enzyme but Not Angiotensin-Convertin Enzyme. The Journal of Biological Chemistry, 281, 30471-30478.

http://dx.doi.org/10.1074/jbc.M605827200

[24] Hersh, L.B. and Rodgers, D.W. (2008) Neprilysin and Amyloid Beta Peptide Degradation. Current Alzheimer Research, 5, 225-231. http://dx.doi.org/10.2174/156720508783954703

[25] Wang, S., Wang, R., Chen, L., Bennett, D.A., Dickson, D.W. and Wang, D.S. (2010) Expression and Functional Profiling of Neprilysin, Insulin Degrading Enzyme and Endothelin Converting Enzyme in Prospectively Studied Elderly and Alzheimer's Brain. Journal of Neurochemistry, 115, 47-57. http://dx.doi.org/10.1111/j.1471-4159.2010.06899.x

[26] Authier, F., Posner, B.I. and Bergeron, J.J. (1996) Insulin-Degrading Enzyme. Clinical \& Investigative Medicine, 19, 149-160.

[27] de Tullio, M.B., Morelli, L. and Castaño, E.M. (2008) The Irreversible Binding of Amyloid Peptide Substrates to Insulin-Degrading Enzyme: A Biological Perspective. Prion, 2, 51-56. http://dx.doi.org/10.4161/pri.2.2.6710

[28] Kingston, I.B., Castro, M.J. and Anderson, S. (1995) In Vitro Stimulation of Tissue-Type Plasminogen Activator by Alzheimer Amyloid Beta-Peptide Analogues. Nature Medicine, 1, 138-142. http://dx.doi.org/10.1038/nm0295-138

[29] Wnendt, S., Wetzels, I. and Gúnzler, W.A. (1997) Amyloid Beta Peptides Stimulate Tissue-Type Plasminogen Activator but Not Recombinant Prourokinase. Thrombosis Research, 85, 217-224. http://dx.doi.org/10.1016/S0049-3848(97)00006-6

[30] Van Nostrand, W.E. and Porter, M. (1999) Plasmin Cleavage of the Amyloid Beta-Protein: Alteration of Secondary Structure and Stimulation of Tissue Plasminogen Activator Activity. Biochemistry, 38, 11570-11576. http://dx.doi.org/10.1021/bi990610f

[31] Tucker, H.M., Kihiko, M., Caldwell, J.N., Wright, S., Kawarabayashi, T., Price, D., et al. (2000) The Plasmin System Is Induced by and Degrades Amyloid-Beta Aggregates. The Journal of Neuroscience, 20, 3937-3946.

[32] Melchor, J.P., Pawlak, R. and Strickland, S. (2003) The Tissue Plasminogen Activator-Plasminogen Proteolytic Cascade Accelerates Amyloid-Beta (Abeta) Degradation and Inhibits Abeta-Induced Neurodegeneration. The Journal of Neuroscience, 23, 8867-8871.

[33] Jacobsen, J.S., Comely, T.A., Martone, R.L., Elokdah, H., Crandall, D.L., Oganesian, A., et al. (2008) Enhanced Clearance of $\mathrm{A} \beta$ in Brain by Sustaining the Plasmin Proteolysis Cascade. Proceedings of the National Academy of Sciences of the United States of America, 105, 8754-8759. http://dx.doi.org/10.1073/pnas.0710823105

[34] Mukherjee, A. and Hersh, L.B. (2002) Regulation of Amyloid Beta-Peptide Levels by Enzymatic Degradation. Journal of Alzheimer's Disease, 4, 341-348.

[35] Strickland, S. (2001) Tissue Plasminogen Activator in Nervous System Function and Dysfunction. Thrombosis and Haemostasis, 86, 138-143.

[36] Kranenburg, O., Gent, Y.Y., Romijn, E.P., Voest, E.E., Heck, A.J. and Gebbink, M.F. (2005) Amyloid-Beta-Stimulated Plasminogen Activation by Tissue-Type Plasminogen Activator Results in Processing of Neuroendocrine Factors. Neuroscience, 131, 877-886. http://dx.doi.org/10.1016/j.neuroscience.2004.11.044

[37] Miners, J.S., Barua, N., Kehoe, P.G., Gill, S. and Love, S. (2011) A $\beta$-Degrading Enzymes: Potential for Treatment of Alzheimer Disease. Journal of Neuropathology \& Experimental Neurology, 70, 944-959. http://dx.doi.org/10.1097/NEN.0b013e3182345e46

[38] Nalivaeva, N.N., Fisk, L.R., Belyaev, N.D. and Turner, A.J. (2008) Amyloid-Degrading Enzymes as Therapeutic Targets in Alzheimer's Disease. Current Alzheimer Research, 5, 212-224. http://dx.doi.org/10.2174/156720508783954785

[39] de Strooper, B. (2010) Proteases and Proteolysis in Alzheimer Disease: A Multifactorial View on the Disease Process. Physiological Reviews, 90, 465-494. http://dx.doi.org/10.1152/physrev.00023.2009

[40] Leal, M.C., Fernandez, A., Morelli, L. and Castaño, E.M. (2009) Cerebral Proteolysis of Amyloid- $\beta$ Peptide: Relevance of Insulin-Degrading Enzyme in Alzheimer's Disease. Medicina (B Aires), 69, 466-472.

[41] Lasierra-Cirujeda, J., Coronel, P., Aza, M.J. and Gimeno, M. (2010) Use of Sulodexide in Patiens with Peripheral Vascular Disease. Journal of Blood Medicine, 1, 105-115. http://dx.doi.org/10.2147/JBM.S10558

[42] Folstein, M.F., Folstein, S.E. and McHugh, P.R. (1975) Mini-Mental State: A Practical Method for Grading the Cognitive State of Patients for the Clinician. Journal of Psychiatric Research, 12, 189-198. http://dx.doi.org/10.1016/0022-3956(75)90026-6

[43] Robles, A., Del Ser, T., Alom, J. and Pefia-Casanova, J. (2002) Propuesta de criterios para el diagnóstico del deterioro cognitivo ligero, la demencia y la enfermedad de Alzheimer. Neurología, 17, 17-32.

[44] Tapia Granados, J.A. (1994) Incidencia: Concepto, terminología y análisis dimensional. Medicina Clínica, 103, 140142. 
[45] Engbers, M.J., van Hylckama Vlieg, A. and Rosendaal, F.R. (2010) Venous Thrombosis in the Elderly: Incidence, Risk Factors and Risk Group. Journal of Thrombosis and Haemostasis, 8, 2105-2112. http://dx.doi.org/10.1111/j.1538-7836.2010.03986.x

[46] Yamamoto, K., Takeshita, K., Kojima, T., Takamatsu, J. and Saito, H. (2005) Aging and Plasminogen Activator Inhibitor-1 (PAI-1) Regulation: Implication in the Pathogenesis of Thrombotic Disorders in the Elderly. Cardiovascular Research, 66, 276-285. http://dx.doi.org/10.1016/j.cardiores.2004.11.013

[47] Tofler, G.H., Massaro, J., Levy, D., Mittleman, M., Sutherland, P., Lipinska, I., et al. (2005) Relation of the Prothrombotic State to Increasing Age (from the Framinghan Offspring Study). American Journal of Cardiology, 96, 1280-1283. http://dx.doi.org/10.1016/j.amjcard.2005.06.072

[48] Lew, S.J. and Lim, J.K. (2002) Stroke Prevention in Elderly Patients with Atrial Fibrillation. Singapore Medical Journal, 43, 198-201.

[49] Zellerhoff, S., Goette, A. and Kirchhof, P. (2006) Anticoagulation with Atrial Fibrillation. Herzschrittmachertherapie \& Elektrophysiologie, 17, 89-94. http://dx.doi.org/10.1007/s00399-006-0515-z

[50] Dhond, A.J., Michelena, H.I. and Ezekowitz, M.D. (2003) Anticoagulation in the Elderly. The American Journal of Geriatric Cardiology, 12, 243-250. http://dx.doi.org/10.1111/j.1076-7460.2003.02010.x

[51] Robert-Ebadi, H., Le Gal, G. and Righini, M. (2009) Use of Anticoagulants in Elderly Patients: Practical Recommendations. Clinical Interventions in Aging, 4, 165-177.

[52] Loskutoff, D.J., Sawdey, M. and Mimuro, J. (1988) Type 1 Plasminogen Activator Inhibitor. In: Coller, B., Ed., Progress in Hemostasis and Thrombosis, WB Saunders, Philadelphia, 87-115.

[53] Yamamoto, K., Takeshita, K., Shimokawa, T., Yi, H., Isobe, K., Loskutof, D.J., et al. (2002) Plasminogen Activator Inhibitor-1 Is a Major Stress-Regulated Gene: Implications for Stress-Induced Thrombosis in Aged Individuals. Proceedings of the National Academy of Sciences of the United States of America, 99, 890-895. http://dx.doi.org/10.1073/pnas.022608799

[54] Naderali, E.K., Ratcliffe, S.H. and Dale, M.C. (2009) Review: Obesity and Alzheimer's Disease: A Link between Body Weight and Cognitive Function in Old Aged. American Journal of Alzheimer's Disease \& Other Dementias, 24, 445-449. http://dx.doi.org/10.1177/1533317509348208

[55] Hashimoto, Y., Kobayashi, A., Yamazaki, N., Sugawara, Y., Takada, Y. and Takada, A. (1987) Relationship between Age and Plasma t-PA, PA-Inhibitor, and PA Activity. Thrombosis Research, 46, 625-633. http://dx.doi.org/10.1016/0049-3848(87)90264-7

[56] Aoyama, K. and Nakaki, T. (2013) Impaired Glutathione Synthesis in Neurodegeneration. International Journal of Molecular Sciences, 14, 21021-21044. http://dx.doi.org/10.3390/ijms141021021

[57] Gu, F., Chauhan, V. and Chauhan, A. (2015) Glutathione Redox Imbalance in Brain Disorders. Current Opinion in Clinical Nutrition \& Metabolic Care, 18, 89-95. http://dx.doi.org/10.1097/MCO.0000000000000134

[58] Cirujeda, J.L. and Granado, P.C. (2006) A Study on the Safety, Efficacy, and Efficiency of Sulodexide Compared with Acenocoumarol in Secondary Prophylaxis in Patients with Deep Venous Thrombosis. Angiology, 57, 53-64. http://dx.doi.org/10.1177/000331970605700108

[59] Marín, F., Roldan, V., Marco, P., Martinez, J.G., Toral, A., García de Burgos, F., et al. (1999) Improvement in Fibrinolytic Function Following Anticoagulant Treatment in Chronic Rheumatic Atrial Fibrillation. Revista Española de Cardiología, 52, 25-30.

[60] Roldán, V., Marin, F., Marco, P., Climent, V., Martinez, J.G., Monmeneu, J.V., et al. (2000) Anticoagulant Therapy Modifies Fibrinolytic Dysfuntion in Chronic Atrial Fibrilation. Haemostasis, 30, 219-224.

[61] van Deelen, B. A., van den Bemt, P.M., Egberts, T.C., van’t Hoff, A. and Maas, H.A. (2005) Cognitive Impairment as Determinant for Sub-Optimal Control of Oral Anticoagulant Treatment in Elderly Patients with Atrial Fibrillation. Drugs \& Aging, 22, 353-360. http://dx.doi.org/10.2165/00002512-200522040-00007

[62] Flaker, G.C., Pogue, J., Yusuf, S., Pfeffer, M. A., Goldhaber, S. Z., Granger, C.B., et al. (2010) Cognitive Function and Anticoagulation Control in Patients with Atrial Fibrillation. Circulation: Cardiovascular Quality and Outcomes, 3, 277-283. http://dx.doi.org/10.1161/CIRCOUTCOMES.109.884171

[63] Jacobs, L.G., Billett, H.H., Freeman, K., Dinglas, C. and Jumaquio, L. (2009) Anticoagulation for Stroke Prevention in Elderly Patients with Atrial Fibrillation, Including Those with Falls and/or Early-Stage Dementia: A Single-Center, Retrospective, Observational Study. The American Journal of Geriatric Pharmacotherapy, 7, 159-166. http://dx.doi.org/10.1016/j.amjopharm.2009.06.002

[64] Singer, D.E., Fang, M.C. and Go, A.S. (2009) The International Normalized Ratio Range of 2.0 to 3.0 Remains Appropriate for Atrial Fibrillation. Archives of Internal Medicine, 169, 2032. http://dx.doi.org/10.1001/archinternmed.2009.419 
[65] Luchsinger, J.A. and Mayeux, R. (2004) Cardiovascular Risk Factors and Alzheimer's Disease. Current Atherosclerosis Reports, 6, 261-266. http://dx.doi.org/10.1007/s11883-004-0056-Z

[66] Gauthier, S., Reisberg, B., Zaudig, M., Petersen, R.C., Ritchie, K., Broich, K., et al. (2006) Mild Cognitive Impairment. The Lancet, 367, 1262-1270. http://dx.doi.org/10.1016/S0140-6736(06)68542-5

[67] Jicha, G.A., Parisi, J.E., Dickson, D.W., Johnson, K., Cha, R., Ivnik, R.J., et al. (2006) Neuropathologic Outcome of Mild Cognitive Impairment Following Progression to Clinical Dementia. Archives of Neurology, 63, 674-681. http://dx.doi.org/10.1001/archneur.63.5.674

[68] Kivipelto, M., Helkala, E.L., Laakso, M.P., Hänninen, T., Hallikainen, M., Alhainen, K., et al. (2001) Midlife Vascular Risk Factors and Alzheimer's Disease in Later Life: Longitudinal, Population Based Study. British Medical Journal, 322, 1447-1451. http://dx.doi.org/10.1136/bmj.322.7300.1447

[69] Weissmann, P., Consalvo, D., Solis, P., Baglivo, H., Ramirez, A. and Sanchez, R. (2002) Hipertension arterial y deterioro cognitivo en el anciano. Revista Argentina de Cardiologia, 70, 231-238.

[70] Skoog, I. and Gustafson, D. (2003) Hypertension, Hypertension-Clustering Factors and Alzheimer's Disease. Neurological Research, 25, 675-680. http://dx.doi.org/10.1179/016164103101201986

[71] Staessen, J.A. and Birkenhäger, W.H. (2004) Cognitive Impairment and Blood Pressure. Hypertension, 44, 612-613. http://dx.doi.org/10.1161/01.HYP.0000145864.95630.20

[72] Anson, O. and Paran, E. (2005) Hypertension and Cognitive Functioning among the Elderly: An Overview. American Journal of Therapeutics, 12, 359-365. http://dx.doi.org/10.1097/01.mjt.00001=09849.55405.48

[73] Skoog, I. and Gustafson, D. (2006) Update on Hypertension and Alzheimer's Disease. Neurological Research, 28, 605-611. http://dx.doi.org/10.1179/016164106X130506

[74] Staessen, J.A., Richart, T. and Birkenhäger, W.H. (2007) Less Atherosclerosis and Lower Blood Pressure for a Meaningful Life Perspective with More Brain. Hypertension, 49, 389-400. http://dx.doi.org/10.1161/01.HYP.0000258151.00728.d8

[75] Elias, M.F. and Dore, G.A. (2008) Brain Indices Predict Blood Pressure Control: Aging Brains and New Predictions. Hypertension, 52, 1014-1015. http://dx.doi.org/10.1161/HYPERTENSIONAHA.108.122713

[76] Elias, M.F., Elias, P.K., Dore, G.A. and Robbins, M.A. (2008) High-Normal Blood Pressure and Cognition: Supplying the Missing Data. Hypertension, 52, e1-e2. http://dx.doi.org/10.1161/HYPERTENSIONAHA.108.114165

[77] Birns, J. and Kalra, L. (2009) Cognitive Function and Hypertension. Journal of Human Hypertension, 23, 86-96. http://dx.doi.org/10.1038/jhh.2008.80

[78] Hofman, A., Ott, A., Breteler, M.M., Bots, M.L., Slooter, A.J., van Harskamp, F., et al. (1997) Atherosclerosis, Apolipoprotein E, and Prevalence of Dementia and Alzheimer's Disease in the Rotterdam Study. The Lancet, 349, 151-154. http://dx.doi.org/10.1016/S0140-6736(96)09328-2

[79] Casserly, I. and Topol, E. (2004) Convergence of Atherosclerosis and Alzheimer 's Disease: Inflammation, Cholesterol, and Misfolded Proteins. The Lancet, 363, 1139-1146. http://dx.doi.org/10.1016/S0140-6736(04)15900-X

[80] Masse, I., Bordet, R., Deplanque, D., Al Khedr, A., Richard, F., et al. (2005) Lipid Lowering Agents Are Associated with a Slower cognitive Decline in Alzheimer's Disease. Journal of Neurology, Neurosurgery \& Psychiatry, 76, 16241629. http://dx.doi.org/10.1136/jnnp.2005.063388

[81] Dimopoulos, N., Piperi, C., Salonicioti, A., Psarra, V., Mitsonis, C., Libersa, I., et al. (2007) Characterization of the Lipid Profile in Dementia and Depression in the Elderly. Journal of Geriatric Psychiatry and Neurology, 20, 138-144. http://dx.doi.org/10.1177/0891988707301867

[82] Michikawa, M. (2003) Cholesterol Paradox: Is High Total or Low HDL Cholesterol Level a Risk for Alzheimer's Disease? Journal of Neuroscience Research, 72, 141-146. http://dx.doi.org/10.1002/jnr.10585

[83] Stefani, M. and Liguri, G. (2009) Cholesterol in Alzheimer's Disease: Unresolved Questions. Current Alzheimer Research, 6, 15-29. http://dx.doi.org/10.2174/156720509787313899

[84] Reitz, C. (2012) Dyslipidemia and Dementia: Current Epidemiology, Genetic Evidence, and Mechanisms behind the Associations. Journal of Alzheimer's Disease, 30, S127-S145.

[85] Anchisi, L., Dessi, S., Pani, A. and Mandas, A. (2012) Cholesterol Homeostasis: A Key to Prevent or Slow Down Neurodegeneration. Frontiers in Physiology, 3, 486-505.

[86] Tan, Z.S., Seshadri, S., Beiser, A., Wilson, P.W., Kiel, D.P., Tocco, M., et al. (2003) Plasma Total Cholesterol Level as Risk Factor for Alzheimer Disease: The Framingham Study. Archives of Internal Medicine, 163, 1053-1057. http://dx.doi.org/10.1001/archinte.163.9.1053

[87] Kálman, J. and Janka, Z. (2005) Cholesterol and Alzheimer’s Disease. Orvosi Hetilap, 146, 1903-1911.

[88] Prasanthi, J., Schommer, E., Thomasson, S., Thompson, A., Feist, G. and Ghribi, O. (2008) Regulation of Beta-Amy- 
loid Levels in the Brain of Cholesterol-Fed Rabbit, a Model System for Sporadic Alzheimer's Disease. Mechanisms of Ageing and Development, 129, 649-655. http://dx.doi.org/10.1016/j.mad.2008.09.002

[89] Ledesma, M.D. and Dotti, C.G. (2005) The Conflicting Role of Brain Cholesterol in Alzheimer's Disease: Lessons from the Brain Plasminogen System. Biochemical Society Symposium, 72, 129-138. http://dx.doi.org/10.1042/bss0720129

[90] Sjögren, M., Mielke, M., Gustafson, D., Zandi, P. and Skoog, I. (2006) Cholesterol and Alzheimer's Disease-Is There a Relation?. Mechanisms of Ageing and Development, 127, 138-147. http://dx.doi.org/10.1016/j.mad.2005.09.020

[91] Ott, A., Stolk, R.P., van Harskamp, F., Pols, H.A., Hofman, A. and Breteler, M.M. (1999) Diabetes Mellitus and the Risk of Dementia: The Rotterdam Study. Neurology, 53, 1937-1942. http://dx.doi.org/10.1212/WNL.53.9.1937

[92] Peila, R., Rodriguez, B.L. and Launer, L. (2002) Type 2 Diabetes, APOE Gene, and the Risk for Dementia and Related Pathologies: The Honolulu-Asia Aging Study. Diabetes, 51, 1256-1262. http://dx.doi.org/10.2337/diabetes.51.4.1256

[93] Grossman, H. (2003) Does Diabetes Protect or Provoke Alzheimer's Disease? Insights into the Pathobiology and Future Treatment of Alzheimer's Disease. CNS Spectrums, 8, 815-823.

[94] Ho, L., Qin, L.W., Pompl, P.N., Xiang, Z., Wang, J., Zhao, Z., et al. (2004) Diet-Induced Insulin Resistance Promotes Amyloidosis in a Transgenic Mouse Model of Alzheimer's Disease. The Federation of American Societies for Experimental Biology Journal, 18, 902-904. http://dx.doi.org/10.1096/fj.03-0978fje

[95] Biessels, G.J. and Kappelle, L.J. (2005) Utrecht Diabetic Encephalopathy Study Group. Increased Risk of Alzheimer’s Disease in Type II Diabetes: Insulin Resistance of the Brain or Insulin-Induce Amyloid Pathology? Biochemical Society Transactions, 33, 1041-1044. http://dx.doi.org/10.1042/BST0331041

[96] Whitmer, R.A. (2007) Type 2 Diabetes and Risk of Cognitive Impairment and Dementia. Current Neurology and Neuroscience Reports, 7, 373-380. http://dx.doi.org/10.1007/s11910-007-0058-7

[97] Roriz-Fiho, J., SA-Roriz, T.M., Rosset, I., Camozzato, A.L., Santos, A.C., Chaves, M.L., et al. (2009) (Pre)Diabetes, Brain Aging, and Cognition. Biochimica et Biophysica Acta, 1792, 432-443. http://dx.doi.org/10.1016/j.bbadis.2008.12.003

[98] Irie, F., Fitzpatrick, A.L., Lopez, O.L., Kuller, L.H., Peila, R., Newman, A.B., et al. (2008) Enhanced Risk for Alzheimer's Disease in Persons with Type 2 Diabetes and APOE Epsilon4. The Cardiovascular Health Study Cognition Study. Archives of Neurology, 65, 89-93. http://dx.doi.org/10.1001/archneurol.2007.29

[99] Akter, K., Lanza, E.A., Martin, S.A., Myronyuk, N., Rua, M. and Raffa, R.B. (2011) Diabetes Mellitus and Alzheimer's Disease: Shared Pathology and Treatment? British Journal of Pharmacology, 71, 365-376. http://dx.doi.org/10.1111/j.1365-2125.2010.03830.x

[100] Janson, J., Laedtke, T., Parisi, J.E., O’Brien, P., Petersen, R.C. and Butler, P.C. (2004) Increased Risk of Type 2 Diabetes in Alzheimer Disease. Diabetes, 53, 474-481. http://dx.doi.org/10.2337/diabetes.53.2.474

[101] Beeler, N., Riederer, B.M., Waeber, G. and Abderrahmani, A. (2009) Role of the JNK-Interacting Protein 1/Islet Brain 1 in Cell Degeneration in Alzheimer Disease and Diabetes. Brain Research Bulletin, 80, 274-281. http://dx.doi.org/10.1016/j.brainresbull.2009.07.006

[102] Abbadini, M., Zhu, G.J., Maggi, A., Pangrazzi, J., Donati, M.B. and Mussoni, L. (1987) Dermatan Sulphate Induces Plasminogen Activator Release in Perfused Rat Hindquarters. Blood, 70, 1858-1860.

[103] Mannarino, E., Pascualini, L., Ciuffetti, G. and Lombardini, R. (1992) Effect of Oral Administration of Sulodexide on Fibrinolysis and Plasma Viscosity: A Pilot Study. Drug Investigation, 4, 346-350. http://dx.doi.org/10.1007/BF03259415

[104] Mauro, M., Palmieri, G.C., Palazzini, E., Barbanti, M., Calanni, F. and Milani, M.R. (1993) Pharmacodynamic Effects of Single and Repeated Doses of Oral Sulodexide in Healthy Volunteers. A Placebo-Controlled Study with an Enteric-Coated Formulation. Current Medical Research and Opinion, 13, 87-95. http://dx.doi.org/10.1185/03007999309111537

[105] Harenberg, J., Jeschek, M., Acker, M., Malsch, R., Huhle, G. and Heene, D.L. (1996) Effects of Low-Molecular Weight Dermatan Sulphate on Coagulation, Fibrinolysis and Tissue Factor Pathway Inhibitor in Healthy Volunteers. Blood Coagulation \& Fibrinolysis, 7, 49-56. http://dx.doi.org/10.1097/00001721-199601000-00006

[106] Colucci, M., Sardella, L., Barbanti, M., Calanni, F. and Semerano, N. (1997) Thrombolysis Enhancing Activity of a Low Molecular Weight Dermatan Sulphate (Desman 370) in Experimental Pulmonary Embolism in Rats. Thrombosis Research, 87, 441-446. http://dx.doi.org/10.1016/S0049-3848(97)00160-6

[107] Castañon, M.M., Gamba, C. and Kordich, L.C. (2007) Insight into the Profibrinolytic Activity of Dermatan Sulfate: Effects on the Activation of Plasminogen Mediated by Tissue and Urinary Plasminogen Activators. Thrombosis Research, 120, 745-752. http://dx.doi.org/10.1016/j.thromres.2006.12.014

[108] Busutti, L. and Breccia, A. (1991) Pharmacokinetics of Sulodexide after Single Oral Administration in Man. European 
Journal of Medical Research, 1, 25-36.

[109] Crepaldi, G., Rossi, A., Coscetti, G., Abbruzzese, E., Calveri, U. and Calabro, A. (1992) Sulodexide Oral Administration Influences Blood Viscosity and Fibrinolysis. Drugs under Experimental and Clinical Research, 18, 189-195.

[110] Ceriello, A., Quatraro, A., Marchi, E., Barbanti, M. and Giugliano, D. (1993) Impaired Fibrinolytic Response to Increased Thrombin Activation in Type 1 Diabetes Mellitus: Eflects of the Glycosaminoglycan Sulodexide. Diabetes \& Metabolism, 19, 225-229.

[111] Jaques, L.B., Hiebert, L.M. and Wice, S.M. (1990) Endothelium as the Major Determinant in the Pharmacodynamic of Heparin and Dextran Sulphate. European Journal of Pharmacology, 183, 369-370. http://dx.doi.org/10.1016/0014-2999(90)93243-J

[112] Milani, M.R., Busutti, L. and Breccia, A. (1992) Pharmacokinetics of Sulodexide Evaluated from 131I-Labelled FastMoving Heparin after Single Intravenous and Oral Administration on Man at Different Doses. British Journal of Clinical Research, 3, 161-178.

[113] Silvestro, L., Lanzarotti, E., Marchi, E., Gori, M., Pescador, R., Ferro, L., et al. (1994) Human Pharmacokinetics of Glycosaminoglicans Using Deuterium-Labelled and Unlabeled Substances: Evidence for Oral Absorption. Seminars in Thrombosis and Hemostasis, 20, 281-292. http://dx.doi.org/10.1055/s-2007-1001914

[114] Leveugle, B., Ding, W., Laurence, F., Dehouck, M.P., Scanameo, A., Cecchellli, R., et al. (1998) Heparin Oligosaccharides That Pass the Blood-Brain Barrier Inhibit Beta-Amyloid Precursor Protein Secretion and Heparin Binding to $\beta$-Amyloid Peptide. Journal of Neurochemistry, 70, 736-744. http://dx.doi.org/10.1046/j.1471-4159.1998.70020736.x

[115] Ma, Q., Dudas, B., Hejna, M., Cornelli, U., Lee, J.M., Lorens, S., et al. (2002) The Blood-Brain Barrier Accessibility of a Heparin-Derived Oligosaccharides C3. Thrombosis Research, 105, 447-453. http://dx.doi.org/10.1016/S0049-3848(02)00050-6

[116] Plow, E.F., Herren, T., Redlitz, A., Miles, L.A. and Hover-Plow, J.L. (1995) The Cell Biology of the Plasminogen System. FASEB Journal, 9, 838-845.

[117] Collen, D. (1999) The Plasminogen (Fibrinolytic) System. Thrombosis and Haemostasis, 82, 259-270.

[118] Hino, H., Akiyama, H., Iseki, E., Kato, M., Kondo, H., Ikeda, K., et al. (2001) Immunohistochemical Localization of Plasminogen Activator Inhibitor-1 in Rat and Human Brain Tissues. Neuroscience Letters, 297, 105-108. http://dx.doi.org/10.1016/S0304-3940(00)01679-7

[119] Cacquevel, M., Launay, S., Castel, H., Benchenane, K., Chéenne, S., Bu’ee, L., et al. (2007) Ageing and Amyloid-Beta Peptide Deposition Contribute to an Impaired Brain Tissue Plasminogen Activator Activity by Different Mechanisms. Neurobiology of Disease, 27, 164-173. http://dx.doi.org/10.1016/j.nbd.2007.04.004

[120] Periz, G. and Fortini, M.E. (2000) Proteolysis in Alzheimer's Disease: Can Plasmin Tip the Balance? The European Molecular Biology Organization Reports, 1, 477-478.

[121] Selkoe, D.J. (2001) Clearing the Brain’s Amyloid Cobwebs. Neuron, 32, 177-180. http://dx.doi.org/10.1016/S0896-6273(01)00475-5

[122] Teesalu, T., Kulla, A., Simisker, A., Sirén, V., Lawrence, D.A., Asser, T., et al. (2004) Tissue Plasminogen Activator and Neuroserpin Are Widely Expressed in the Human Central Nervous System. Thrombosis and Haemostasis, 92, 358-368. http://dx.doi.org/10.1160/th02-12-0310

[123] Aoyagi, T., Wada, T., Kojima, F., Nagai, M. and Takeuchi, T. (1994) Age-Dependent Decreases in Fibrinolytic Enzyme Activities in Serum of Healthy Subjects. Biological and Pharmaceutical Bulletin, 17, 348-351. http://dx.doi.org/10.1248/bpb.17.348

[124] Aoyagi, T., Wada, T., Kojima, F., Harada, S., Takeuchi, T., Isse, K., et al. (1992) Deficiency of Fibrinolytic Enzyme Activities in the Serum of Patients with Alzheimer-Type Dementia. Experientia, 48, 656-659. http://dx.doi.org/10.1007/BF02118312

[125] Tanzi, R.E., Moir, R.D. and Wagner, S.L. (2004) Clearance of Alzheimer’s A $\beta$ Peptide. The Many Roads to Perdition. Neuron, 43, 605-608.

[126] Zlokovic, B.V. (2004) Clearing Amyloid through the Blood-Brain Barrier. Journal of Neurochemistry, 89, 807-811. http://dx.doi.org/10.1111/j.1471-4159.2004.02385.x

[127] Lasierra, J., Aza, M.J., Collado, P.S., Gonzalez, J. and Esteller, A. (1989) Inhibition of Fibrinolysis by Cellular Glutathione Depletion in the Rabbit. Thrombosis Research, 5, 347-355. http://dx.doi.org/10.1016/0049-3848(89)90313-7

[128] Ledesma, M.D., Da Silva, J.S., Crassaerts, K., Delacourte, A., De Strooper, B. and Dotti, C.G. (2000) Brain Plasmin Enhances APP Alpha-Cleavage and Abeta Degradation and Is Reduced in Alzheiemer's Disease Brains. The European Molecular Biology Organization Reports, 1, 530-535.

[129] Yasojima, K., Akiyama, H., Mcgeer, E.G. and Mcgeer, P.L. (2001) Reduced Neprilysin in High Plaque Areas of Alzheimer Brain: A Possible Relationship to Deficient Degradation of Beta-Amyloid peptide. Neuroscience Letters, 297, 
97-100. http://dx.doi.org/10.1016/S0304-3940(00)01675-X

[130] Saito, T., Takaki, Y., Iwata, N., Trojanowski, J. and Saido, T.C. (2003) Alzheimer's Disease, Neuropeptides, Neuropeptidase, and Amyloid- $\beta$ Peptide. Science of Aging Knowledge Environment, 2003, pe1. http://dx.doi.org/10.1126/sageke.2003.3.pe1

[131] Wang, D.S., Iwata, N., Hama, E., Saido, T.C. and Dickson, D.W. (2003) Oxidized Neprilysin in Aging and Alzheimer’s Disease Brains. Biochemical and Biophysical Research Communications, 310, 236-241. http://dx.doi.org/10.1016/j.bbrc.2003.09.003

[132] Ledesma, M.D., Abad-Rodriguez, J., Galvan, C., Biondi, E., Navarro, P., Delacourte, A., et al. (2003) Raft Disorganization Leads to Reduced Plasmin Activity in Alzheimer's Disease Brains. The European Molecular Biology Organization Reports, 4, 1190-1196. http://dx.doi.org/10.1038/sj.embor.7400021

[133] Wang, D.S., Lipton, R.B., Katz, M.J., Davies, P., Buschke, H., Kuslansky, G., et al. (2005) Decrease Neprilysin Immunoreactivity in Alzheimer Disease, but Not in Pathological Aging. Journal of Neuropathology \& Experimental Neurology, 64, 378-385. http://dx.doi.org/10.1093/jnen/64.5.378

[134] Russo, R., Borghi, R., Markesbery, W., Tabaton, M. and Piccini, A. (2005) Neprylisin Decreases Uniformly in Alzheimer's Disease and in Normal Aging. Federation of European Biochemical Societies Letters, 579, 6027-6030. http://dx.doi.org/10.1016/j.febslet.2005.09.054

[135] Miners, J.S., Baig, S., Palmer, J., Palmer, L.E., Kehoe, P.G. and Love, S. (2008) A $\beta$-Degrading Enzymes in Alzheimer's Disease. Brain Pathology, 18, 240-252. http://dx.doi.org/10.1111/j.1750-3639.2008.00132.x

[136] Hellström-Lindahl, E., Ravid, R. and Nordberg, A. (2008) Age Dependent Decline of Neprilysin in Alzheimer's Disease and Normal Brain: Inverse Correlation with A Beta Levels. Neurobiology of Aging, 29, 210-221. http://dx.doi.org/10.1016/j.neurobiolaging.2006.10.010

[137] Vaughan, D.E., De Taeye, B.M. and Eren, M. (2007) PAI-1 Antagonists: Predictable Indications and Unconventional Applications. Current Drug Targets, 8, 962-970. http://dx.doi.org/10.2174/138945007781662364

[138] Eren, M., Gleaves, L.A., Atkinson, J.B., Le, R., Declerck, P.J. and Vaughan, D.E. (2007) Reactive Site-Dependent Phenotypic Alterations in Plasminogen Activactor Inhibitor-1 Transgenic Mice. Journal of Thrombosis and Haemostasist, 5, 1500-1508. http://dx.doi.org/10.1111/j.1538-7836.2007.02587.x

[139] Akhter, H., Katre, A., Li, L., Liu, X. and Liu, R.M. (2011) Therapeutic Potential and Anti-Amyloidosis Mechanisms of Tert-Butylhydroquinone for Alzheimer's Disease. Journal of Alzheimer's Disease, 26, 767-778.

[140] Jones, D.P. (2002) Redox Potential of GSH/GSSG Couple: Assay and Biological Significance. Methods in Enzymology, 348, 93-112. http://dx.doi.org/10.1016/S0076-6879(02)48630-2

[141] Bains, J.S. and Shaw, C.A. (1997) Neurodegenerative Disorders in Human: the Role of Glutathione in Oxidative Stress-Mediated Neuronal Death. Brain Research Reviews, 25, 335-358. http://dx.doi.org/10.1016/S0165-0173(97)00045-3

[142] Lu, S.C. (1999) Regulation of Hepatic Glutathione Synthesis: Current Concepts and Controversies. The Federation of American Societies for Experimental Biology Journal, 13, 1169-1183.

[143] Griffith, O.W. (1999) Biologic and Pharmacologic Regulation of Mammalian Glutathione Synthesis. Free Radical Biology \& Medicine, 27, 922-935. http://dx.doi.org/10.1016/S0891-5849(99)00176-8

[144] Aoyama, K., Suh, S.W., Hamby, A.M., Liu, J., Chan, W.Y., Chen, Y., et al. (2006) Neuronal Glutathione Deficiency and Age-Dependent Neurodegeneration in the EAAC1 Deficient Mouse. Nature Neuroscience, 9, 119-126. http://dx.doi.org/10.1038/nn1609

[145] Byrd, A.S., Sikorska, M., Walker, P.R. and Sandhu, J.K. (2004) Effects of Glutathione Depletion on the Viability of Human NT2-Derived Neuronal and Astroglial Cultures. Neuron Glia Biology, 1, 317-328. http://dx.doi.org/10.1017/S1740925X05000207

[146] Lee, M., Cho, T., Jantaratnotai, N., Wang, Y.T., McGeer, E. and McGeer, P.L. (2010) Depletion of GSH in Glial Cells Induces Neurotoxicity: Relevance to Aging and Degenerative Neurological Diseases. The Federation of American Societies for Experimental Biology Journal, 24, 2533-2545. http://dx.doi.org/10.1096/fj.09-149997

[147] Barker, J.E., Heales, S.J., Cassidy, A., Bolaños, J.P., Land, J.M. and Clark, J.B. (1996) Depletion of Brain Glutathione Results in a Decrease of Glutathione Reductase Activity; An Enzyme Susceptible to Oxidative Damage. Brain Research, 716, 118-122. http://dx.doi.org/10.1016/0006-8993(96)00003-0

[148] Mizui, T., Kinouchi, H. and Chan, P.H. (1992) Depletion of Brain Glutathione by Buthionine Sulfoximine Enhances Cerebral ischemic Injury in Rats. American Journal of Physiology, 262, H313-H317.

[149] Mytilineou, C., Leonardi, E.K., Radcliffe, P.H., Heinonen, E.H., Han, S.K., Werner, P., et al. (1998) Deprenyl and Desmethylselegiline Protect Mesencephalic Neurons from Toxicity Induced by Glutathione Depletion. Journal of Pharmacology and Experimental Therapeutics, 284, 700-706.

[150] Li, Y., Maher, P. and Schubert, D. (1997) A Role for 12-Lipoxygenase in Nerve Cell Death Caused by Glutathione 
Depletion. Neuron, 19, 453-463. http://dx.doi.org/10.1016/S0896-6273(00)80953-8

[151] Sandhu, J.K., Gardaneh, M., Iwasiow, R., Lanthier, P., Gangaraju, S., Ribbeco-Lutkiewicz, M., et al. (2009) Astrocyte-Secreted GDNF and Glutathione Antioxidant System Project Neurons against 6OHDA Cytotoxicity. Neurobiology of Disease, 33, 405-414. http://dx.doi.org/10.1016/j.nbd.2008.11.016

[152] Liu, R. and Choi, J. (2000) Age-Associated Decline in Gamma-Glutamylcysteine Sinthetase Gene Expression in Rats. Free Radical Biology \& Medicine, 28, 566-574. http://dx.doi.org/10.1016/S0891-5849(99)00269-5

[153] Liu, H., Wang, H., Shenvi, S., Hagen, T.M. and Liu, R.M. (2004) Glutathione Metabolism during Aging and in Alzheimer Disease. Annals of the New York Academy of Sciences, 1019, 346-349. http://dx.doi.org/10.1196/annals.1297.059

[154] Tchaikovskaya, T., Fraifeld, V., Urphanishvili, T., Andorfe, J.H., Davies, P. and Listowsky, I. (2005) Glutathione S-Transferase hGSTM3 and Ageing-Associated Neurodegeneration: Relationship to Alzheimer's Disease. Mechanisms of Ageing and Development, 126, 309-315. http://dx.doi.org/10.1016/j.mad.2004.08.029

[155] Zhu, Y., Carvey, P.M. and Ling, Z. (2006) Age-Related Changes in Glutathione and Glutathione-Related Enzymes in Rat Brain. Brain Research, 1090, 35-44. http://dx.doi.org/10.1016/j.brainres.2006.03.063

[156] Butterfield, D.A., Perluig, M. and Sultana, R. (2006) Oxidative Stress in Alzheimer's Disease Brain: New Insights from Redox Proteomics. European Journal of Pharmacology, 545, 39-50. http://dx.doi.org/10.1016/j.ejphar.2006.06.026

[157] Sian, J., Dexter, D.T., Lees, A.J., Daniel, S., Agid, Y., Javoy-Agid, F., et al. (1994) Alterations in Glutathione Level in Parkinson's Disease and Other Neurodegeneratives Disorders Affecting Basal Ganglia. Annals of Neurology, 36, 348-355. http://dx.doi.org/10.1002/ana.410360305

[158] Good, P.F., Werner, P., Hsu, A., Olanow, C.W. and Perl, D.P. (1996) Evidence of Neuronal Oxidative Damage in Alzheimer's Disease. American Journal of Pathology, 149, 21-28.

[159] Townsend, D.M., Tew, K.D. and Tapiero, H. (2003) The Importance of Glutathione in Human Disease. Biomedicine \& Pharmacotherapy, 57, 145-55. http://dx.doi.org/10.1016/S0753-3322(03)00043-X

[160] Yoshida, K., Hirokawa, J., Tagami, S., Kawakami, Y., Urata, Y. and Kondo, T. (1995) Weakened Cellular Scavenging Activity against Oxidative Stress in Diabetes Mellitus: Regulation of Glutathione Synthesis and Efflux. Diabetologia, 38, 201-210. http://dx.doi.org/10.1007/BF00400095

[161] Regan, R.F. and Guo, Y. (1999) Extracellular Reduced Glutathione Increases Neuronal Vulnerability to Combined Chemical Hypoxia and Glucose Deprivation. Brain Research, 817, 145-150. http://dx.doi.org/10.1016/S0006-8993(98)01252-9

[162] Sharma, A., Kharb, S., Chugh, S.N., Kakkar, R. and Singh, G.P. (2000) Effect of Glycemic Control and Vitamin E Supplementation on Total Glutathione Content in Non-Insulin-Dependent Diabetes Mellitus. Annals of Nutrition and Metabolism, 44, 11-13. http://dx.doi.org/10.1159/000012815

[163] Giral, P., Jacob, N., Dourmap, C., Carrié, A., Bruckert, E., Girerd, X., et al. (2008) Elevated Gammaglutamyltransferase Activity and Perturbed Thiol Profile Are Associated with Features of Metabolic Syndrome. Arteriosclerosis, Thrombosis, and Vascular Biology, 28, 587-593. http://dx.doi.org/10.1161/ATVBAHA.107.157891

[164] Ballatori, N., Krance, S.M., Notenboom, S., Shi, S., Tieu, K. and Hammond, C.L. (2009) Glutathione Dysregulation and the Etiology and Progression of Human Diseases. Biological Chemistry, 390, 191-214. http://dx.doi.org/10.1515/BC.2009.033

[165] Samiec, P.S., Drews-Botsch, C., Flagg, E.W., Kurtz, J.C., Sternberg, P., Reed, R.L., et al. (1998) Glutathione in Human Plasma: Decline in Association with Aging, Age-Related Macular Degeneration, and Diabetes. Free Radical Biology \& Medicine, 24, 699-704. http://dx.doi.org/10.1016/S0891-5849(97)00286-4

[166] Lasierra-Cirujeda, J., Aza, M.J., Lasierra-Ibañez, A. and Aza, M.M. (1991) AGING: Thromboembolic Disease, Metabolic Syndrome, Type 2 Diabetes Mellitus, and Alzheimer Disease. In Publication Phase.

[167] Vague, P., Raccah, D. and Scelles, V. (1995) Hypofibrinolysis and the Insulin Resistance Syndrome. International Journal of Obesity and Related Metabolic Disorders, 19, S11-S15.

[168] Juhan-Vague, I., Alessi, M.C. and Vague, P. (1996) Thrombogenic and Fibrinolytic Factors and Cardiovascular Risk in Non-Insulin-Dependent Diabetes Mellitus. Annals of Medicine, 28, 371-380. http://dx.doi.org/10.3109/07853899608999095

[169] Juhan-Vague, I. and Alessi, M.C. (1997) PAI-1, Obesity, Insulin Resistance and Risk of Cardiovascular Events. Thrombosis and Haemostasis, 78, 656-660.

[170] Juhan-Vague, I., Alessi, M.C. and Morange, P.E. (2000) Hypofibrinolysis and Increased PAI-1 Are Linked to Atherothrombosis via Insulin Resistance and Obesity. Annals of Medicine, 32, 78-84.

[171] Farris, W., Mansourian, S., Chang, Y., Lindsley, L., Eckman, E.A., Frosch, M.P., et al. (2003) Insulin-Degrading En- 
zyme Regulates the Levels of Insulin, Amyloid Beta-Protein, and the Beta-Amyloid Precursor Protein Intracellular Domain in Vivo. Proceedings of the National Academy of Sciences of the United States of America, 100, 4162-4167. http://dx.doi.org/10.1073/pnas.0230450100

[172] Juhan-Vague, I., Alessi, M.C., Mavri, A. and Morange, P.E. (2003) Plasminogen Activator Inhibitor-1 Inflammation, Obesity, Insulin Resistance and Vascular Risk. Journal of Thrombosis and Haemostasis, 1, 1575-1579. http://dx.doi.org/10.1046/j.1538-7836.2003.00279.x

[173] Skurk, T. and Hauner, H. (2004) Obesity and Impaired Fibrinolysis: Role of Adipose Production of Plasminogen Activator Inhibitor-1. International Journal of Obesity and Related Metabolic Disorders, 28, 1357-1364. http://dx.doi.org/10.1038/sj.ijo.0802778

[174] Mavri, A., Alessi, M.C. and Juhan-Vague, I. (2004) Hypofibrinolysis in the Insulin Resistance Syndrome: Implication in Cardiovascular Diseases. Journal of Internal Medicine, 255, 448-456. http://dx.doi.org/10.1046/j.1365-2796.2003.01288.x

[175] Alessi, M.C. and Juhan-Vague, I. (2006) PAI-1 and the Metabolic Syndrome: Links, Causes, and Consequences. Arteriosclerosis, Thrombosis, and Vascular Biology, 26, 2200-2207. http://dx.doi.org/10.1161/01.ATV.0000242905.41404.68

[176] Dimova, E.Y., Samoylenko, A. and Kietzmann, T. (2004) Oxidative Stress and Hypoxia: Implications for Plasminogen Activator Inhibitor-1 Expression. Antioxidants \& Redox Signaling, 6, 777-791. http://dx.doi.org/10.1089/1523086041361596

[177] Vayalil, P.K., Olman, M., Murphy-Ullrich, J.E., Postlethwait, E.M. and Liu, R.M. (2005) Glutathione Restores Collagen Degradation in TGF- $\beta$-Treated Fibroblasts by Blocking Plasminogen Activator Inhibitor-1 Expression and Activating Palsminogen. American Journal of Physiology. Lung Cellular and Molecular Physiology, 289, L937-1945. http://dx.doi.org/10.1152/ajplung.00150.2005

[178] Kutz, S., Hordines, J., McKeown-Longo, P.J. and Higgins, P.J. (2001) TGF- $\beta 1$-Induced PAI-1 Gene Expression Requires MEK Activity and Cell-to-Substrate Adhesion. Journal of Cell Science, 114, 3905-3914.

[179] Kutz, S.M., Higging, C.E., Samarakoon, K., Higging, S.P., Allen, R.R., Qi, L., et al. (2006) TGF-Beta 1-Induced PAI-1 Expression Is Ebox/USF-Dependent and Requires EGFR Signal in. Experimental Cell Research, 312, 10931105. http://dx.doi.org/10.1016/j.yexcr.2005.12.027

[180] Fain, J.N., Tichansky, D.S. and Madan, A.K. (2005) Transforming Growth Factor Beta 1 Release by Human Adipose Tissue Enhanced Obesity. Metabolism, 54, 1546-1551. http://dx.doi.org/10.1016/j.metabol.2005.05.024

[181] Herder, C., Zierer, A., Koenig, W., Roden, M., Meisinger, C. and Thorand, B. (2009) Transforming Growth Factor- $\beta 1$ and Incident Type 2 Diabetes: Results from the MONICA/KORA Case-Cohort Study, 1984-2002. Diabetes Care, 32, 1921-1923. http://dx.doi.org/10.2337/dc09-0476

[182] Kutz, S.M., Higgins, C.E. and Higgins, P.J. (2012) Novel Combinatorial Targeting of PAI-1 (SERPINE1) Gene Expression in Alzheimer's Disease. Molecular Medicine \& Therapeutics, 1, 2. http://dx.doi.org/10.4172/2324-8769.1000106

[183] Higgins, P.J. (2006) The TGF- $\beta 1 /$ Upstream Stimulatory Factor-Regulated PAI-1 Gene: Potential Involvement and a Therapeutic Target in Alzheimer's Disease. Journal of Biomedicine and Biotechnology, 2006, Article ID: 15792. http://dx.doi.org/10.1155/jbb/2006/15792

[184] Martina, V., Bruno, G.A., Pannocchia, A., Zumpano, E., Tagliabue, M. and Trucco, A., et al. (1996) PAI-1 Reduction after Treatment with Glutathione in NIDDM. Fibrinolysis, 10, 63-65. http://dx.doi.org/10.1016/S0268-9499(96)80052-X

[185] Martina, V., Bruno, G.A., Zumpano, E., Origlia, C., Quaranta, L. and Pescarmona, G.P. (2001) Administration of Glutathione in Patients with Type 2 Diabetes Mellitus Increases the Platelet Constitutive Nitric Oxide Synthase Activity and Reduces PAI-1. Journal of Endocrinological Investigation, 24, 37-41. http://dx.doi.org/10.1007/BF03343806

[186] Perego, M., Palmieri, G. and Nazzari, M. (1982) Effects of Oral and Parenteral 3-GS Administration on Blood Lipids and Haemostatic Parameters in Atherosclerotic Hyperlipaemic Patients. In: Lenzi, S. and Descovich, C.G., Eds., Atherosclerosis: Etiopathogenesis, Clinical Evaluation and Therapy, Editrice Compositori, Bologna, 157-163.

[187] Bonacci, C., Crolle, G., Olivi, A., Romagnoli, G., Marchetto, N., et al. (1986) Effetti del sulodexide in pazienti anziani con vasculopatia arteriosclerotica cerebrale [Effects of Sulodexide in Elderly Patients with Artherosclerotic Cerebral Vascular Disease]. Acta gerontologica, 36, 228-235.

[188] Capone-Braga, M., Tellini, L., Boncompagni, L., Bettoni, M., Burali, A. and Bensi, A. (1987) Approccio terapeutico con sulodexide in pazienti con vasculopatia aterosclerotica a varia localizzazione [Sulodexide Treatment Approach in Patients with Atherosclerotic Vascular Disease with Various Localizations]. Clinical Therapeutics, 120, 25-31.

[189] Cospite, M., Milio, G., Ferrara, F., et al. (1985) Double-Blind Study of the Pharmacological Effect of Sulodexide in Patients with Multiple Atherosclerotic Vascular Disease. European Review for Medical and Pharmacological Sciences, 
7, 97-106.

[190] Bonanno, G., Bonaccorso, R., Dell’Ali, C. and Salanitri, G. (1985) Sulodexide in the Treatment of Atherosclerosis: A Controlled Clinical Trial. Acta Therapeutica, 11, 87-98.

[191] Postiglione, F., Pisani, P., Gisonni, P., Perrota, P., Gisonni, M., et al. (1986) Sulodexide in the Therapy of Vasculopathies. Clinical Therapeutics, 117, 223-231.

[192] Santus, G., Sottini, G., Lombardi, G., Rozzini, R. and Inzoli, R. (1984) L’uso del sulodexide nei vasculopatici cerebrali con dislipidemia e/o diabete: Contributo clinico statistico. In: Lenci, S. and Descovich, G.C., Eds., Atherosclerosis and Cardiovascular Diseases, Editrice Compositori, Bologna, 415-420.

[193] Parnetti, L., Mari, D., Abate, G., Balestreri, R., Cucinotta, D., Coppola, R., et al. (1997) Vascular Dementia Italian Sulodexide Study (VA.D.I.S.S.). Clinical and Biological Results. Thrombosis Research, 87, 225-233. http://dx.doi.org/10.1016/S0049-3848(97)00122-9

[194] Rodriguez-Martinez, M.A. and Ruiz-Torres, A. (1992) Homeostasis between Lipid Peroxidation and Antioxidant Enzyme Activities in Healthy Human Aging. Mechanisms of Ageing and Development, 66, 213-222. http://dx.doi.org/10.1016/0047-6374(92)90137-3

[195] Klapcinska, B., Derejczyk, J., Wieczorowska-Tobis, K., Sobezak, A., Sadowska-Krepa, E., et al. (2000) Antioxidant Defense in Centenarians (a Preliminary Study). Acta Biochimica Polonica, 47, 281-292.

[196] Mari, D., Mannucci, P., Coppola, R., Bottassao, B., Bauer, K.A. and Rosenberg, R.D. (1995) Hypercoagulability in Centenarians: The Paradox of Successful Aging. Blood, 85, 3144-3149.

[197] Mari, D., Oglian, G., Casataldi, D., Vitale, G., Bollini, E.M. and Lio, D. (2008) Hemotasis and Ageing. Immunity \& Ageing, 5, 12. http://dx.doi.org/10.1186/1742-4933-5-12 